\title{
EXAMINING THE IMPACT OF COVID-19 PANDEMIC ON TOURISM SECTOR USING INPUT-OUTPUT ANALYSIS: THE CASE OF CROATIA
}

\author{
Davor Mikulić \\ Damira Keček \\ Željko Lovrinčević
}

https://doi.org//10.20867/tosee.06.29

\begin{abstract}
Purpose - The purpose of the study is to determine the impact of COVID-19 pandemic on tourism and other economic sectors included in the tourism value chain in Croatia. The evaluation of total effects is important in order to evaluate effectiveness of policy measures introduced by Croatian government.

Methodology - The estimation of COVID -19 effects on Croatian economy is based on standard input-output model. The open I-O model quantifies indirect effects generated in the tourism value added chain. Closed I-O model estimates induced effects related to the decrease in the net disposable income of the employees which participated in the tourism sector production chain. Findings - Strong reduction in international tourism caused by COVID -19 resulted in significant decrease in activity of many other industries. Besides hotels and restaurant, the most affected sectors were transport, trade, food industry, sports and entertainment services. Total value of indirect and induced tourism effects is bigger than value of direct effects in terms of employment and value added because of multiplier effect. Government subsidies in the form of income support for companies which retained employees have only short-term and limited effects. Negative COVID - 19 effects were partially mitigated by output rise in other domestic sectors. GDP decline was more pronounced than GVA since indirect taxes, notably VAT and excise duties were particularly sensitive to negative trends in tourism activity.

Contribution - The methodology applied provides the reliable analytical background for analyses of impact of negative exogenous shock affecting tourism and total Croatian economy and assessment of government policy response effectiveness.
\end{abstract}

Keywords: COVID -19, input-output analysis, total effects, tourism sector.

\section{INTRODUCTION}

As the coronavirus spread globally in 2020, authorities in many countries intervened by health and other measures. The transmission control policies could result in serious economic costs. Social isolation, limitations of certain activities and restriction in the mobility had a significant economic impact, especially on the activities such as tourism and trade. According to the latest UNWTO World Tourism Barometer (UNWTO 2021), in 2020 global tourism suffered its worst year. Number of international arrivals dropped by $74 \%$ and destinations worldwide received 1 billion fewer international tourists comparing to the previous year. The collapse in international travel is estimated to loss in tourism revenues of around USD 1.3 trillion and therefore between 100 and 120 million direct tourism jobs have been put at risk. While tourism sector contributed to $10 \%$ of global GDP and 6\% of the world's total exports in the period 2015-2019, its 
ToSEE - Tourism in Southern and Eastern Europe, Vol. 6, pp. 439-453, 2021.

D. Mikulić, D. Keček, Ž. Lovrinčević: EXAMINING THE IMPACT OF COVID-19 PANDEMIC ON ...

contribution in 2020 is expected to be significantly lower. Croatia has been recognized as one of the most popular European destinations due to rich cultural-historical heritage and natural conditions. Croatia is one of the countries with the largest share of tourism revenues in GDP, positioning tourism in the group of key economic sectors. In the period after 2009 the number of foreign tourists has been steadily increasing for approximately two million arrivals per year.

Epidemiological measures and recommendations to limit mobility to prevent the transmission of COVID-19 disease have influenced a whole range of economic activities, but tourism has been most affected. The aim of this paper is to determine the impact of COVID-19 pandemic on tourism and other economic sectors included in the value chain of tourism in Croatia. The evaluation of total effects, including direct, indirect and induced effects, are important in order to evaluate whether policy measures introduced by Croatian government to combat economic crisis have been appropriate. Total effects of tourism sector on Croatian economy are quantified in terms of total output, gross value added (GVA) and employment. In this research, the estimation of direct, indirect and induced effects of the reduction of tourism sector due to COVID-19 is based on standard open and closed input-output (IO) model. The open input-output model was applied to quantify indirect effects generated in the economic sectors involved in the value-added chain of the tourism sector. Closed IO model was used to estimate total effects including induced effects related to the reduction in the net disposable income of the employees which work in companies producing goods and services directly or indirectly demanded by tourists. IO model quantifies Leontief type I and type II multipliers for tourism activity in Croatia. The methodology applied provides the reliable analytical background for analyses of impact of negative exogenous shock affecting tourism as one of the key sectors of the Croatian economy. Data reflecting current tourism situation could be important for policy makers in formulating economic policy measures which could speed up the recovery of tourism activity after pandemic and to support development of all sectors which directly or indirectly participate in tourism.

The paper is organized as follows. The introduction is followed by an overview of the recent and relevant literature of tourism impact on national economies. In section 2 the research methodology is described, while section 3 presents data sources. Empirical results are presented in section 4 . In the conclusion final remarks are provided.

\section{LITERATURE REVIEW}

According to recent studies (Fernandes 2020), service-oriented economies are expected to be most heavily hit by the outbreak of COVID-19 virus. Negative economic effects caused by health measures directly affect services, but negative effects are also expected to spill over to the rest of the economy throughout the value-added chain. Fernandes (2020) estimated that each additional month of restrictions results in the reduction in the economy in range of 2.5-3\% of GDP. Fornaro and Wolf (2020) showed that the spread of the epidemic firstly presents a negative shock of declining demand, followed by a decrease in supply and continued negative spiral effects. Literature have described various transmission channels through tourism that impact the rest of the economy. Baldwin and Di Mauro (2020) pointed that on the supply side, the lockdown and travel 
ToSEE - Tourism in Southern and Eastern Europe, Vol. 6, pp. 439-453, 2021.

D. Mikulić, D. Keček, Ž. Lovrinčević: EXAMINING THE IMPACT OF COVID-19 PANDEMIC ON ...

restrictions reduce productivity and employment, while demand effects are related to the reduction in household income and consumption. Declining demand and supply are interrelated, and the intensity of economic downturn are increasing through longer period. Loayza and Pennings (2020) suggested the application of short-term measures aimed at avoiding layoffs and bankruptcy of companies during restrictions on the human contacts. Even easing of restrictions require formulation of economic policy stimulating economic recovery and coordination of monetary and fiscal policy.

Total economic effects of tourism certainly go beyond direct effects faced by tourism companies. Indirect effects of tourism and the role of tourism in socio-economic development has been explored in literature over decades by different approaches and methods applied. An overview of analytical background of different approaches for evaluation of economic effects of tourism has been presented in Kumar and Hussain (2014). The set of methods includes Keynesian models, exports base models, computable general equilibrium models, monetary approach and other methods, but IO method is most used to estimate economic contribution of tourism to the national economy. Total effects of tourism prior 2020 crisis are mainly focused on positive economic effects. A comprehensive list of IO studies on the tourism contribution can be found in Tohmo (2018). Tohmo (2018) found that tourism has a substantial economic impact in Central Finland where foreign tourism expenditures in the hotel and restaurant sector induce $11.5 \%$ of employment (390 employees) and expenditures on transport accounted for additional $2.3 \%$ of employment. Ferreira, Ramos and Lahr (2020) estimated that Lisbon guesthouses are creating more than 29,400 jobs in Portugal increasing gross domestic product by $0.5 \%$. Also, regional dispersion of benefits is found and approximately $50 \%$ of gains redistributed outside Lisbon. Surugiu, Frent and Surugiu (2009) examined the impact in changes in final demand for composite sector which includes hotels, restaurants and travel agencies on Romanian economy. They calculated backward and forward linkage coefficients for output, earnings, GVA and employment. The intensity of backward linkage placed the sector to the eleventh position from total of 19 sectors, while low forward linkage coefficients reveal the orientation of output to mostly final demand. IO model was also applied for South Africa (Saayman, Saayman and Naudé 2011) where positive contribution of hotels and restaurants has been found. Atan and Arslanturk (2012) analyzed the significance of tourism in Turkey and classified hotels and restaurants as one of the key sectors for Turkey economy.

The contribution of Croatian tourism sector was also estimated by IO model. Šutalo, Ivandić and Marušić (2011) focused on the role of tourism and the measurement of the multiplicative effects of tourism consumption on the different industries. Authors estimated that tourism generates $14.7 \%$ of Croatian GVA in 2005. Ivandić and Šutalo (2018) applied the same methodological framework for more recent period and concluded that tourism contribution is ranging from 14.2 to $16.3 \%$ of Croatian GVA The IO model was used to estimate direct and indirect effects of tourism sector by Jurčić (1998) and Gelo (2016), and the results of both studies found significant effects of tourism in Croatia. While Ivandić and Šutalo (2018) estimates contribution of both, domestic and foreign tourists, Mikulić, Keček and Žajdela Hrustek (2017) were focused on the multiplicative effects of expenditures of foreign tourists and found increasing economic impacts from $13.1 \%$ of Croatian GVA in 2010 to $16.2 \%$ in 2014. 
ToSEE - Tourism in Southern and Eastern Europe, Vol. 6, pp. 439-453, 2021.

D. Mikulić, D. Keček, Ž. Lovrinčević: EXAMINING THE IMPACT OF COVID-19 PANDEMIC ON ...

While studies conducted before 2020 were concentrated on positive economic effects of tourism, recent studies are dealing with estimation of economic impacts of negative exogenous shock caused by COVID-19 outbreak. Beckman and Morse (2020) stressed that tourism is an activity which is the most disturbed by shocks caused by natural, economic, political or health crises. Natural disasters such us earthquakes, droughts or tornados could destroy hospitality facilities or decrease the attractiveness of the devastated area for potential visitors. Political instability, wars or terrorism are political factors also negatively affect tourism. Economic recessions, coupled with decreasing employment and household income, such as recorded in 2009, could also limit the mobility of tourists. In the last two decades, health concerns played a more significant role in decisions of tourists whether to travel at all and potential destination. Examples of events which disrupted the smooth trend of growing global tourism were terrorist attack on the September 11, 2001, the SARS pandemic outbreak in 2002-2003, the 2008/2009 global recession, Ebola outbreak of 2013-2014, and Zika epidemic outbreak of 2017 (Beckman and Morse 2020).

All the above events presented only temporary disruptions in global travel, and tourism showed to be a resistant industry which rapidly rebound after negative exogenous shocks (Gössling, Scott and Hall 2020). However, the intensity and duration of COVID-19 crisis could induce stronger negative economic effects. Mariolis, Rodousakis and Soklis (2020) estimated that decrease of international travel receipts in the Greek economy in 2020 due to outbreak of COVID-19 pandemic could induce a decrease in Greek GDP in range from $2.0 \%$ to $6.0 \%$. Employment could decrease of about $2.1 \%$ to $6.4 \%$ and trade balance deficit could reach 2.4 to 7.1 billion euros. Besides sector Hotels and restaurants, the most affected sectors are Land transport, Agriculture, and Real estate. Because of the significant employment multiplier, hotels and restaurants are estimated to suffer only $31 \%$ of total employment loss. Giammetti, Papi Teobaldelli and Ticchi (2020) explored the role of the domestic value chain in transmitting COVID-19 lockdown measures to Italian economy. They combined traditional IO model with complex network analysis to reveal key industries affected by lockdown. Stopping the production of many key sectors in period of strict lockdown, results in decrease of $52 \%$ of total circulating value added, of which $30 \%$ presents indirect effects along value chains. They found that even sectors that are not subjected to lockdown, such as financial, professional, transport and information services, agriculture, ICT sector, energy, gas, water and waste industry have been significantly affected lockdown. Ribeiro, Santos, Cerqueira and Souza (2020) estimated the economic impact of pandemic COVID-19 on the tourism in Brazil. Based on the method of partial hypothetical extraction they estimate the potential effects at $31 \%$ of GDP related to tourism sector. However, the government subsidies could mitigate some of negative effects and reduce it to $17 \%$.

\section{RESEARCH METHODOLOGY}

IO analysis is traditional macroeconomic method, broadly described in the previous literature and only a short outline of the method is presented in this section. IO table presents the flows of goods and services among sectors in an economy. In its simplest form, IO examines effects of changes in final demand on output, GVA and employment required to deliver demanded products (Miller and Blair 2009). 
ToSEE - Tourism in Southern and Eastern Europe, Vol. 6, pp. 439-453, 2021. D. Mikulić, D. Keček, Ž. Lovrinčević: EXAMINING THE IMPACT OF COVID-19 PANDEMIC ON ...

Total output of sector $i$ is delivered to other economic sectors to be used as intermediate consumption and final demand as described by the equation (1):

$X_{i}=\sum_{j=1}^{n} X_{i j}+Y_{i}, i=1, \ldots, n$

$X_{i}$ is total output of sector $i, X_{i j}$ represents deliveries of intermediate products from sector $i$ to sector $j$, while $Y_{i}$ represents the final demand for that product. Technical coefficient $a_{i j}=\frac{X_{i j}}{X_{j}}$ is defined as the ratio of the value of intermediate inputs delivered from sector $i$ that is required to produce one unit of product by sector $j$. By introducing technical coefficient, the equation (1) can be written as:

$X_{i}=\sum_{j=1}^{n} a_{i j} X_{j}+Y_{i}, i=1, \ldots, n$

The system of linear equations describing total economy consisting of $n$ sectors can be written in matrix form as:

$X=A X+Y$

where $X=\left[\begin{array}{c}X_{1} \\ \vdots \\ X_{n}\end{array}\right]$ is column vector of outputs produced by economic sectors, $Y=\left[\begin{array}{c}Y_{1} \\ \vdots \\ Y_{n}\end{array}\right]$ is column vector of final demands and $A=\left[\begin{array}{ccc}a_{11} & \cdots & a_{1 n} \\ \vdots & \ddots & \vdots \\ a_{n 1} & \cdots & a_{n n}\end{array}\right]$ is a square $n \times n$ matrix of technical coefficients, usually called technology matrix.

If certain mathematical conditions are satisfied, i.e. if the matrix $I-A$ is non-singular and positive definite matrix, where $I$ is an $n \times n$ identity matrix, total output in an economy is result of the final demand as presented by equation (4):

$X=(I-A)^{-1} Y$

Matrix $(I-A)^{-1}$ is Leontief Inverse matrix, also known in literature as multiplier matrix. Equation (4) points to the relation where total output depends on exogenously given final demand. Element $\alpha_{i j}$ of the Leontief Inverse matrix presents the output of sector $i$ which is required, directly and indirectly, to deliver one unit of output produced by sector $j$ which is used in final demand.

Economic literature identifies two types of multipliers, type I and type II multipliers. Open IO model in which all components of final demand are considered as exogenous provides type I multipliers which include the direct and indirect effects. In closed IO model certain component of final demand, usually personal consumption of households, is endogenous, depending on labor income which in turn depends on level of output. Closed IO models result in type II multipliers which include direct, indirect and induced effects (McLennan 2006). Discussion whether open or closed model provides more robust estimates is inconclusive. Grady and Muller (1988) and Miller and Blair (2009) 
ToSEE - Tourism in Southern and Eastern Europe, Vol. 6, pp. 439-453, 2021.

D. Mikulić, D. Keček, Ž. Lovrinčević: EXAMINING THE IMPACT OF COVID-19 PANDEMIC ON ...

argued that type I multipliers could underestimate while type II multipliers overestimate total effects. While type I multiplier is based on the Leontief Inverse matrix $(I-A)^{-1}$ indicating direct and indirect effects on the production, in calculation of the type II multiplier, an extended matrix $(I-\bar{A})^{-1}$ is used. Matrix $\bar{A}$ is expanding technology matrix $A$ with an additional row, representing coefficients of labor income and an additional column, representing household consumption coefficients. Elements of matrix $(I-\bar{A})^{-1}$ present total effects including direct, indirect and induced effects resulting from increased consumption which is financed by additional labor income.

\section{DATA SOURCES}

Study is based on Croatian IO table for 2017 which separate total economy into 64 mutually exclusive economic sectors. In the short period, potential changes in technical coefficients are limited and it is assumed that estimated total effects are reliable. Calculations are originally conducted on IO table which disaggregates total economy into 64 sectors, but for easier presentation, results are summarized in the aggregated sectors according to the international Classification of Products by Activities (CPA) as presented by Table 1 .

Table 1: Definition of aggregated sectors

\begin{tabular}{ll}
\hline CPA Code & Description of the aggregate sector \\
\hline A & Agriculture, forestry and fishing \\
B,C,D,E & Manufacturing, mining and quarrying and other industries \\
F & Construction \\
G,H & Wholesale and retail trade, transportation, storage \\
I & Accommodation and food service activities \\
J & Information and communication \\
K & Financial and insurance activities \\
L & Real estate activities \\
M,N & Professional, scientific, technical, administrative and support services \\
O,P,Q & Public administration and defense, education, human health and social work \\
R,S,T,U & Other services \\
\hline
\end{tabular}

Source: CPA classification (www.dzs.hr)

Furthermore, data required for GVA and employment contribution calculation are downloaded from the Eurostat National accounts aggregates by industry (nama_10_a64) and from the Eurostat National accounts employment data by industry (nama_10_a64_e) (http://ec.europa.eu/eurostat/data/database). Officially available IO table do not provide expenditures of foreign tourist as a separate item of final demand. In order to separate expenditures of domestic population and foreign tourists, additional data has been used and expenditures of foreign tourists in Croatia are based on combination of different data sources. Total expenditures of foreign tourists are available from Balance of Payments (BoP) statistics which is regularly published by Croatian National Bank (CNB). Revenues from services provided to foreign travelers and tourists are recorded under the item Travel in BoP data. Methodology for the travel revenues calculation is described in detail in CNB publications (https://www.hnb.hr/en/analyses-and-publications/regularpublications/bulletin). 
ToSEE - Tourism in Southern and Eastern Europe, Vol. 6, pp. 439-453, 2021.

Figure 1: Trends in expenditures of foreign tourists in Croatia

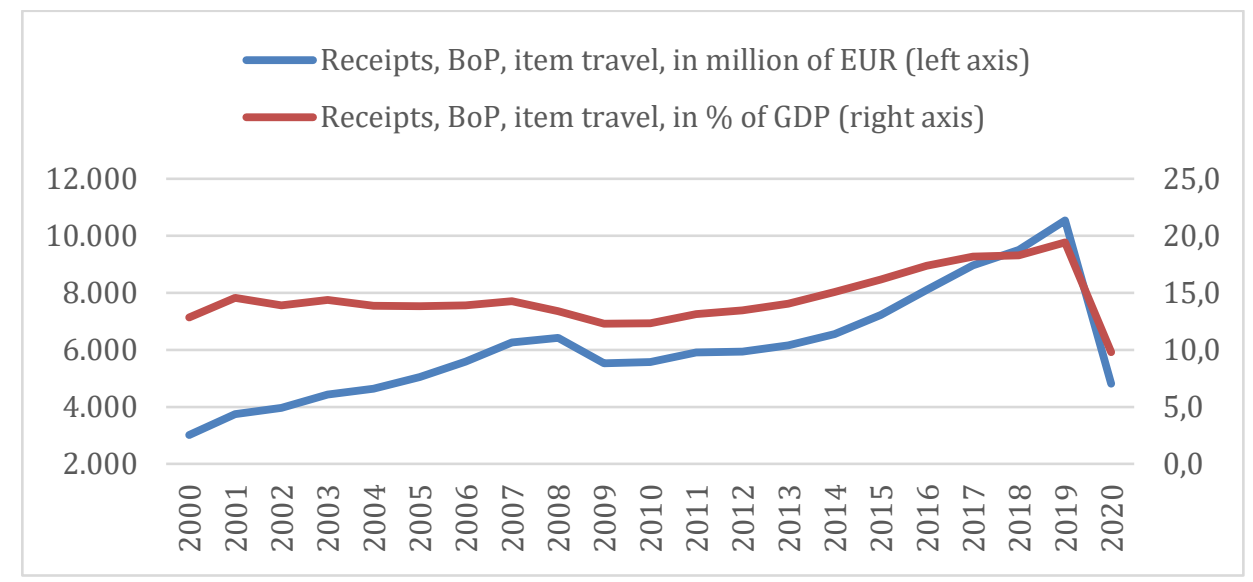

Source: CNB for receipts, CBS for GDP. *Data for 2020 are not final.

Structure of expenditures of foreign tourists is available from TOMAS survey conducted by Institute for Tourism (Marušić et al. 2020). Institute has been conducting TOMAS survey as a multiannual research. While previous surveys, conducted in 2007, 2010, 2014 and 2017, were focused on consumption of tourists in summer period, 2019 survey covered expenditures in Adriatic and Continental Croatia in period from May 2019 to March 2020. The 2019 survey is based on the same methodology as previous TOMAS Summer surveys, but results are representative for total Croatian tourism demand. Sample size and analytical techniques applied assure the representatively by region, type of accommodation, season and country of origin.

Total daily expenses as estimated by TOMAS survey are presented by Table 2 . For better comparability of expenditures in various periods, Table 2 presents expenditures referenced to summer period and Adriatic Croatia. According to the survey, accommodation services are the most important item in total expenditures with the share of above $50 \%$ of total expenditures. Food and beverages consumed in bars and restaurants comprise $17.3 \%$ of expenditures, while all other expenditures on products bought in retail trade and other services are under $30 \%$ of total expenditures. Other services are in TOMAS survey disaggregated to sport and recreation, culture, entertainment services and trips during holiday which is useful for application of IO model at more detailed level.

The average daily expenditures were growing steadily and in 2019 were higher by $60.4 \%$ than in 2010. Expenditures on recreational, entertainment and other services were the most dynamic component of total expenditures and were almost double in 2019 than in 2010. High growth is also recorded for food and beverages consumed in bars and restaurants, while expenditures in retail trade showed the lowest increase. Data on structure of daily expenditures and number of tourist nights' total expenditures on travel, as recorded in BoP statistics, could be broken down to be comparable to economic sectors as captured by an input output table. 
ToSEE - Tourism in Southern and Eastern Europe, Vol. 6, pp. 439-453, 2021.

D. Mikulić, D. Keček, Ž. Lovrinčević: EXAMINING THE IMPACT OF COVID-19 PANDEMIC ON ...

Table 2: The expenditures of foreign tourists settled in Adriatic Croatia during summer season in EUR, results of TOMAS surveys

\begin{tabular}{lrrrrrr}
\hline & 2010 & 2014 & 2017 & 2019 & $\begin{array}{r}\text { Index } \\
2019 / 2010\end{array}$ & $\begin{array}{r}\text { Share } \\
2019\end{array}$ \\
\hline $\begin{array}{l}\text { Average daily } \\
\text { expenditures }\end{array}$ & 58 & 66.4 & 78.8 & 93.0 & 160.4 & 100.0 \\
$\begin{array}{l}\text { Accommodation services } \\
\text { (including food in the }\end{array}$ & 33.89 & 36.2 & 38.8 & 50.4 & 148.7 & 54.2 \\
$\begin{array}{l}\text { residence object) } \\
\begin{array}{l}\text { Food and beverages in } \\
\text { bars and restaurants }\end{array}\end{array}$ & 9.08 & 12.2 & 13.0 & 16.1 & 176.9 & 17.3 \\
$\begin{array}{l}\text { Expenditures in retail } \\
\text { trade }\end{array}$ & 7.92 & 9.5 & 12.0 & 11.0 & 138.4 & 11.8 \\
Other services & 7.11 & 8.5 & 15.0 & 15.6 & 219.3 & 16.8 \\
\hline
\end{tabular}

Source: TOMAS survey 2010, 2014, 2017 and 2019. (methodology and results are presented in Marušić et al. 2020): http://www.iztzg.hr/hr/institut/projekti/istrazivanja/

\section{RESEARCH RESULTS}

Economic effects of foreign tourists' expenditures in Croatia for the period 2015-2020 are based on the methodology described in previous chapter. Total GVA effects of foreign tourists' expenditures are expressed as the sum of direct, indirect and induced effects and presented in Figure 2. An upward trend in GVA effects related to tourism can be noticed until 2019, when total contribution of foreign tourists' expenditures on Croatian GVA was estimated at 60 billion of HRK. In 2020, due to the COVID-19 pandemic, tourist arrivals and thus revenues from foreign tourists, decreased significantly. Compared to the previous year, in 2020 total GVA induced by foreign tourists' expenditures reduced to 27.8 billion of HRK and decreased by $54 \%$.

Figure 2: Total contribution of foreign tourists' expenditures to Croatian GVA, in billions of HRK

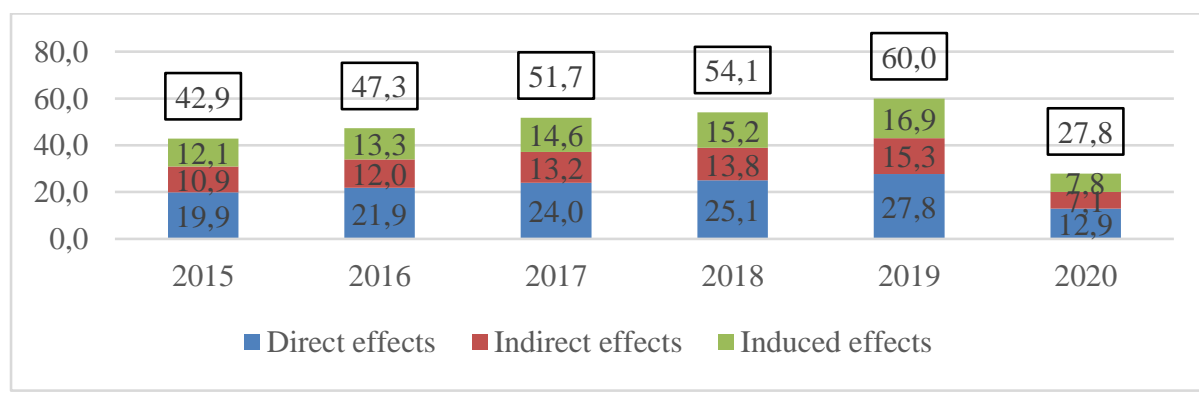

Source: authors' calculations.

In order to prevent the spread of coronavirus, strict epidemiological measures were introduced, travel was restricted, and international borders were partially closed. It directly affected the decline in tourist arrivals and overnight stays, and thus caused a 
ToSEE - Tourism in Southern and Eastern Europe, Vol. 6, pp. 439-453, 2021.

D. Mikulić, D. Keček, Ž. Lovrinčević: EXAMINING THE IMPACT OF COVID-19 PANDEMIC ON ...

significant decline in economic activity and jobs depending on tourism. The number of jobs in terms of full time equivalent (FTE) that should be induced by international tourism consumption is shown by Figure 3. Labor requirements decreased by 173 thousand of FTE jobs in 2020 because of reduced international tourism while keeping labor productivity unchanged. Total employment in Croatia in 2020 dropped just by 11,3 thousand employees instead of 173 thousand $(323,4-150,2)$ as predicted. Labor productivity decreased substantially because of COVID-19 employment subsidies.

Figure 3: Total contribution of foreign tourists' expenditures to Croatian employment, in thousands of annual FTE jobs

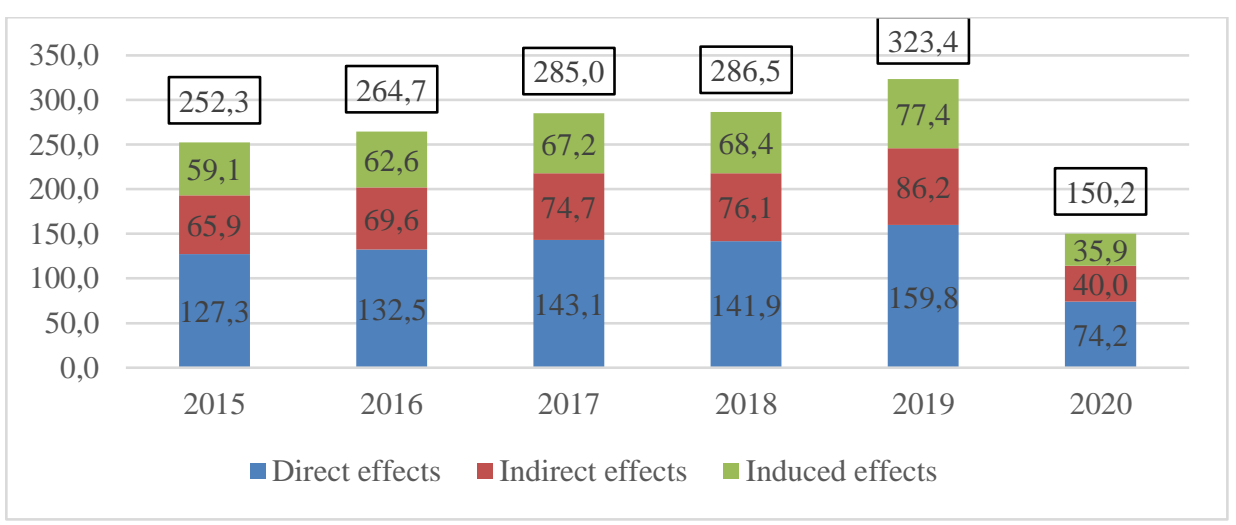

Source: authors' calculations

Devastating effects on Croatian labor market and social condition of potentially unemployed persons were partially prevented by government grants for firms which retained employees (Figure 4). In 2020 government paid 8.3 billion HRK for employers which retain employees. On average, monthly number of employees receiving grant were 229 thousand, with significant monthly oscillations depending on intensity of COVID19 restrictions.

Figure 4: Government grants for preserving employment and number of employees covered in 2020

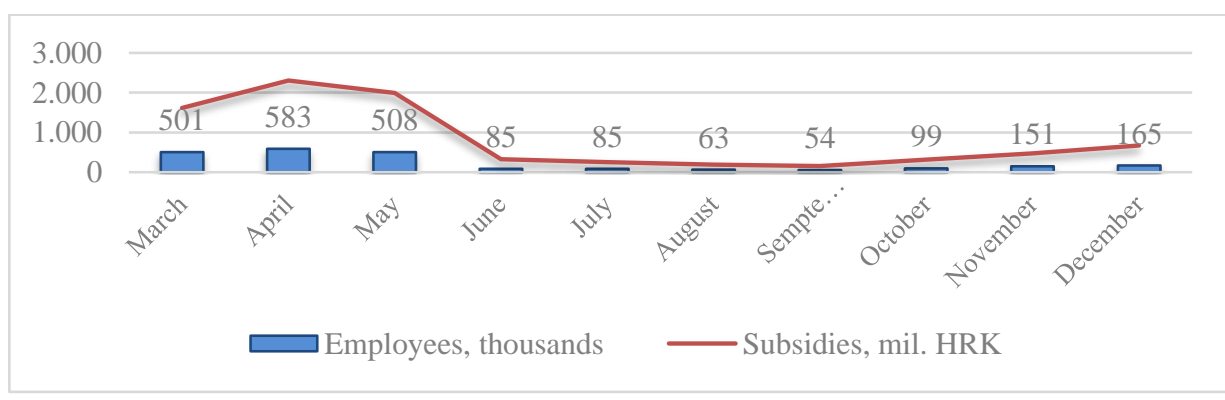

Source: https://mjera-orm.hzz.hr/korisnici-potpore/statistika-prosinac-2020/ . 
ToSEE - Tourism in Southern and Eastern Europe, Vol. 6, pp. 439-453, 2021.

D. Mikulić, D. Keček, Ž. Lovrinčević: EXAMINING THE IMPACT OF COVID-19 PANDEMIC ON ...

Over $33 \%$ of GVA effects induced by the demand of foreign tourists was realized in Accommodation and food services. Besides accommodation and food services, the most intensive impact of international tourism is recorded in the manufacturing industry, trade, transportation, real estate and other business and personal services (Table 3). COVID-19 induced significant decline in all industries along the value-added chain of tourism industry.

Table 3: Total GVA induced by expenditures of foreign tourists according to aggregated sectors, in billions of HRK

\begin{tabular}{lrrrrrr}
\hline CPA Code & 2015 & 2016 & 2017 & 2018 & 2019 & 2020 \\
\hline A & 1.6 & 1.8 & 2.0 & 2.2 & 2.4 & 1.1 \\
B+C+D+E & 7.9 & 8.9 & 9.6 & 10.0 & 11.1 & 5.1 \\
F & 0.3 & 0.3 & 0.3 & 0.4 & 0.4 & 0.2 \\
G+H & 7.5 & 8.2 & 9.0 & 9.4 & 10.4 & 4.8 \\
I & 14.4 & 15.8 & 17.3 & 18.1 & 20.1 & 9.3 \\
J & 1.1 & 1.3 & 1.3 & 1.5 & 1.6 & 0.8 \\
K & 1.8 & 2.0 & 2.3 & 2.4 & 2.7 & 1.2 \\
L & 2.9 & 3.2 & 3.5 & 3.6 & 4.0 & 1.9 \\
M+N & 2.1 & 2.2 & 2.5 & 2.5 & 2.8 & 1.3 \\
O+P+Q & 0.8 & 1.0 & 1.1 & 1.2 & 1.3 & 0.6 \\
R+S+T & 2.3 & 2.6 & 2.8 & 2.8 & 3.2 & 1.5 \\
\hline Total & 42.9 & 47.3 & 51.7 & 54.1 & 60.0 & 27.8 \\
\hline
\end{tabular}

Source: authors' calculations.

Dependence of industries on tourism receipts can be assessed by the share of GVA of an industry induced by expenditures of foreign tourists (Table 4).

Table 4: Share of total GVA of aggregated sector induced by consumption of foreign tourists in GVA of Croatian economy, in billions of HRK

\begin{tabular}{lrrrrrr}
\hline CPA Code & 2015 & 2016 & 2017 & 2018 & 2019 & 2020 \\
\hline A & 17.3 & 18.7 & 20.6 & 20.9 & 22.7 & 9.1 \\
B+C+D+E & 12.4 & 13.5 & 14.2 & 14.5 & 15.7 & 8.6 \\
F & 2.4 & 2.5 & 2.6 & 2.4 & 2.5 & 0.9 \\
G+H & 15.0 & 15.9 & 16.5 & 16.0 & 16.9 & 8.9 \\
I & 72.1 & 74.6 & 75.9 & 75.7 & 79.6 & 68.9 \\
J & 7.9 & 8.4 & 8.5 & 8.7 & 9.1 & 4.3 \\
K & 10.2 & 11.2 & 12.1 & 13.1 & 14.1 & 6.6 \\
L & 10.9 & 11.9 & 12.8 & 13.1 & 14.2 & 6.2 \\
M+N & 12.4 & 12.5 & 13.5 & 13.5 & 14.4 & 5.2 \\
O+P+Q & 2.2 & 2.4 & 2.5 & 2.5 & 2.6 & 1.1 \\
R+S+T & 26.2 & 26.5 & 26.9 & 26.7 & 28.4 & 13.9 \\
\hline Total & 15.2 & 16.4 & 17.1 & 17.1 & 18.2 & 8.5 \\
\hline
\end{tabular}

Source: authors' calculations.

Economic sectors most dependent on international tourism are hotels and restaurants (I) where foreign tourists induced approximately $80 \%$ of GVA in 2019 and other personal services $(\mathrm{R}+\mathrm{S}+\mathrm{T})$ with share of nearly $30 \%$. Some other sectors such as transport, trade, 
ToSEE - Tourism in Southern and Eastern Europe, Vol. 6, pp. 439-453, 2021.

D. Mikulić, D. Keček, Ž. Lovrinčević: EXAMINING THE IMPACT OF COVID-19 PANDEMIC ON ...

agriculture and food industry, as well as various business and personal services also significant part of GVA create by production of goods and services which are directly or indirectly delivered to foreign tourists.

Table 5: Total employment effects induced by expenditures of foreign tourists according to sectors, in thousands of FTE jobs

\begin{tabular}{lrrrrrr}
\hline CPA Code & 2015 & 2016 & 2017 & 2018 & 2019 & 2020 \\
\hline A & 22.5 & 20.0 & 20.7 & 19.3 & 21.7 & 10.0 \\
B+C+D+E & 41.1 & 45.0 & 48.5 & 51.4 & 59.2 & 27.5 \\
F & 2.1 & 2.3 & 2.4 & 2.5 & 2.9 & 1.4 \\
G+H & 48.7 & 52.1 & 57.6 & 56.3 & 63.6 & 29.5 \\
I & 91.6 & 93.4 & 101.9 & 101.0 & 114.4 & 53.1 \\
J & 4.1 & 5.0 & 4.8 & 6.0 & 6.6 & 3.1 \\
K & 5.3 & 5.9 & 7.6 & 7.2 & 7.4 & 3.4 \\
L & 3.0 & 3.4 & 3.6 & 3.5 & 3.8 & 1.8 \\
M+N & 10.1 & 11.4 & 12.0 & 12.2 & 13.6 & 6.3 \\
O+P+Q & 7.4 & 7.7 & 8.3 & 8.6 & 10.2 & 4.7 \\
R+S+T & 16.4 & 18.5 & 17.6 & 18.5 & 20.0 & 9.4 \\
\hline Total & 252.3 & 264.7 & 285.0 & 286.5 & 323.4 & 150.2 \\
\hline
\end{tabular}

Source: authors' calculations.

Table 6: The importance of international tourism by economic sectors, the share of jobs induced by international tourism

\begin{tabular}{|c|c|c|c|c|c|c|}
\hline CPA Code & 2015 & 2016 & 2017 & 2018 & 2019 & 2020 \\
\hline A & 17.9 & 19.1 & 21.1 & 21.4 & 23.7 & 11.2 \\
\hline $\mathrm{B}+\mathrm{C}+\mathrm{D}+\mathrm{E}$ & 12.3 & 13.3 & 14.0 & 14.2 & 15.8 & 7.4 \\
\hline $\mathrm{F}$ & 2.4 & 2.5 & 2.6 & 2.4 & 2.7 & 1.2 \\
\hline $\mathrm{G}+\mathrm{H}$ & 14.8 & 15.8 & 16.4 & 16.0 & 17.8 & 8.4 \\
\hline I & 72.1 & 74.6 & 75.9 & 75.7 & 83.9 & 39.6 \\
\hline J & 7.6 & 8.2 & 8.4 & 8.7 & 9.7 & 4.6 \\
\hline $\mathrm{K}$ & 13.9 & 15.2 & 16.9 & 16.5 & 18.3 & 8.5 \\
\hline $\mathrm{L}$ & 19.9 & 21.6 & 21.9 & 21.5 & 23.9 & 10.0 \\
\hline $\mathrm{M}+\mathrm{N}$ & 13.2 & 13.3 & 14.3 & 19.9 & 15.7 & 7.4 \\
\hline $\mathrm{O}+\mathrm{P}+\mathrm{Q}$ & 2.4 & 2.5 & 2.6 & 2.6 & 2.9 & 1.4 \\
\hline $\mathrm{R}+\mathrm{S}+\mathrm{T}$ & 29.0 & 29.7 & 29.4 & 29.5 & 32.6 & 17.3 \\
\hline Total & 16.2 & 16.9 & 17.8 & 17.4 & 19.1 & 8.9 \\
\hline
\end{tabular}

Source: authors' calculations.

Number of persons employed induced by foreign tourists' spending in the observed period recorded continuous growth in all sectors and in 2019 amounted to more than 323 thousand (Table 5). It can be concluded that approximately 19\% of Croatian jobs in 2019 depended on international tourism (Table 6).

Total employment directly or indirectly induced by international tourism decreased by approximately $50 \%$ in 2020 . In hotels and restaurants, the share of jobs induced by tourism dropped from $83.9 \%$ in 2019 to $39.6 \%$ in 2020 while wages for huge number of employees have been financed by government grants. 
ToSEE - Tourism in Southern and Eastern Europe, Vol. 6, pp. 439-453, 2021.

D. Mikulić, D. Keček, Ž. Lovrinčević: EXAMINING THE IMPACT OF COVID-19 PANDEMIC ON ...

Table 7 presents effects of consumption of foreign tourists on Croatian GVA in constant prices. In the period 2015-2019 receipts from foreign tourists positively contributed to the rate of growth, unlike in 2020, when a significant negative contribution was recorded. It is interesting to note that GVA of other sectors which do not depend on international tourism, but other components of final demand are rising in 2020 by $3.8 \%$. Sectors which recorded economic growth in pandemic were construction, health and other public services, agriculture, ICT and some branches of manufacturing industry, notably pharmacy, which produce tradable goods and benefited by reduction of imports caused by disruptions in international trade. Tourism sector multiplier is obviously important but rather shallow what prevented Croatian economy from even deeper GDP decline.

Table 7. Impact of expenditures of foreign tourists on Croatian GVA in real terms

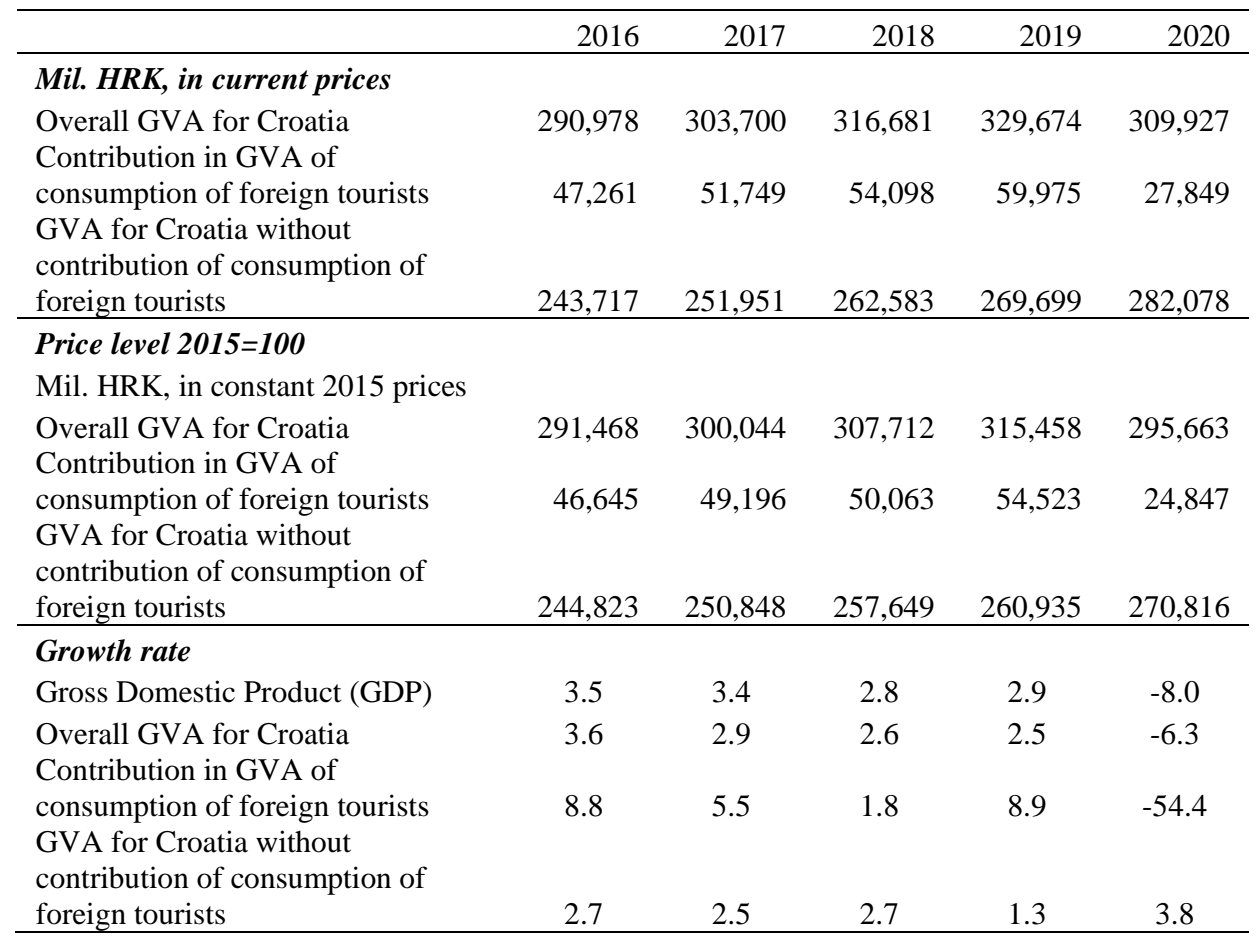

Source: authors' calculations.

\section{CONCLUSION AND IMPLICATIONS}

Until 2020, tourism was the most important sector contributing to the economic growth of Croatian economy. The analysis of the share of total GVA induced by the consumption of foreign tourists in the GVA of the Croatian economy, ranging from 15.2 percent in 2015 to 18.2 percent in 2019, confirms the previously recognized high importance of the tourism sector for the Croatian economy (Šutalo, Ivandić and Marušić 2011; Ivandić and Šutalo 2018; Mikulić, Keček and Žajdela Hrustek 2017). Epidemiological measures and 
ToSEE - Tourism in Southern and Eastern Europe, Vol. 6, pp. 439-453, 2021.

D. Mikulić, D. Keček, Ž. Lovrinčević: EXAMINING THE IMPACT OF COVID-19 PANDEMIC ON ...

recommendations to prevent the transmission of COVID-19 disease have influenced a whole range of economic activities in 2020, but tourism has been most affected. Total contribution of foreign tourists' expenditures on Croatian GVA and employment in 2020, compared to the previous period, decreased by approximately $50 \%$. Besides hotels and restaurant, the most affected economic sectors are transport, trade, food industry, sports, entertainment, recreational and personal services. Total value of indirect and induced effects is bigger than value of direct effects in terms of employment and value added because of multiplier effect. Approximately 19\% of all Croatian jobs in 2019 were induced by international tourism.

Negative COVID-19 effects were partially mitigated by rise in other domestic sector output, mostly agriculture, construction, agriculture and some of manufacturing industries. It created economic situation where negative trends are less pronounced in terms of GVA than GDP aggregate. GDP and public finance trends are more sensitive to VAT taxes and excise duties where tourism activity plays important role. It might point to the fact that in near future it is expected to see the same economic patterns of recovery mostly based on EU funds and rising activity in construction, agriculture and green energy projects. Public deficit and debt consolidation, which depends heavily on indirect taxes and tourism will be lagging overall economic recovery. That might put significant limitations on public expenditures even in the long run.

To mitigate the disturbances in the economy caused by the pandemic, government provides grants to support companies to gain access to liquidity in order to preserve the continuity of their economic activity and to preserve employment. However, government subsidies have only short-term and limited effects on one hand. On the other some structural changes in Croatian economy are irreversible and any attempt to postpone them might turn out to be counterproductive in medium term framework. Therefore, data found by an input-output model reflecting current tourism situation could be important for policy makers in formulating economic policy measures which should speed up the recovery of tourism activity after pandemic. But shallow tourism multiplier might not be enough to speed up overall economic recovery which brings us back to the idea of speeding up overall reform agenda.

The recommendations for future research are mainly directed to the estimation of the regional economic impact of tourism in Croatia. The results on the overall effects of tourism in the Croatian regions, Continental and Adriatic, could be important in determining goals and priorities of Croatia's regional development.

\section{REFERENCES}

Atan, S. and Arslanturk, Y. (2012), "Tourism and economic growth nexus: an input output analysis in Turkey", Procedia - Social and Behavioral Sciences, Vol. 62, pp. 952-956. http://dx.doi.org/10.1016/j.sbspro.2012.09.162

Beckman, E. and Morse, S. (2020), "The Local Economic Impact of the COVID-19 Pandemic on the Hospitality Industry", Journal of Advanced Management Science, Vol. 8, No. 3, pp. 98-102. doi: 10.18178/joams.8.3.98-102

Ferreira, J.P., Ramos, P.N. and Lahr, M.L. (2020), "The rise of the sharing economy: Guesthouse boom and the crowding-out effects of tourism in Lisbon", Tourism economics, Vol. 26, No. 3, pp. 389-403. doi: $10.1177 / 1354816619839849$ 
ToSEE - Tourism in Southern and Eastern Europe, Vol. 6, pp. 439-453, 2021.

D. Mikulić, D. Keček, Ž. Lovrinčević: EXAMINING THE IMPACT OF COVID-19 PANDEMIC ON ...

Fernandes, N. (2020), "Economic Effects of Coronavirus Outbreak (COVID-19) on the World Economy", Social Science Research Network (SSRN). IESE Business School Working Paper No. WP-1240-E, viewed 20 April 2020, https://ssrn.com/abstract=3557504

Fornaro, L. and Wolf, M. (2020), "COVID-19 Coronavirus and Macroeconomic Policy", Social Science Research Network (SSRN). CEPR Discussion Paper No. DP14529, viewed 20 April 2020, https://ssrn.com/abstract=3560337

Gelo, T. (2016), "Economic Impacts of Tourism in Croatia", in New Challenges and Boundaries in Tourism: Policies, Innovations and Strategies, International Association for Tourism Policy, Napulj, Italija, pp. $48-48$.

Grady, P. and Muller, R.A. (1988), "On the use and misuse of input-output based impact analysis in evaluation", The Canadian Journal of Program Evaluation, Vol. 3, No. 2, pp. 49-61.

Giammetti, R., Papi, L., Teobaldelli, D. et al. (2020), "The Italian value chain in the pandemic: the inputoutput impact of Covid-19 lockdown", J. Ind. Bus. Econ. Vol. 47, pp. 483-497. https://doi.org/10.1007/s40812-020-00164-9

Gül, H. (2015), "Effects of foreign demand increase in the tourism industry: a CGE approach to Turkey", An International Journal of Tourism and Hospitality Research, Vol. 26, pp. 598-611. http://dx.doi.org/10.1080/13032917.2015.1044016

Ivanić, N. and Šutalo, I. (2018), "The contribution of tourism to the Croatian Economy: An IO approach", Ekonomski Pregled, Vol. 69, No. 1, pp. 20-42. doi:10.32910/ep.69.1.2

Jurčić, Lj. (1998), "The multiplying effects of Croatian tourism", Acta turistica, Vol. 10, No. 2, pp. 128-149.

Kumar, J. and Hussain, K. (2014), "Evaluating tourism's economic effects: Comparison of different approaches", Procedia - Social and Behavioral Sciences, Vol. 144, pp. 360-365. https://doi.org/10.1016/j.sbspro.2014.07.305

Loayza, N.V. and Pennings, S. (2020), "Macroeconomic Policy in the Time of COVID-19:A Primer for Developing Countries", Research \& Policy Briefs, 28, Worldbank, viewed 20 April 2020, https://openknowledge.worldbank.org/bitstream/handle/10986/33540/Macroeconomic-Policy-inthe-Time-of-COVID-19-A-Primer-for-Developing-Countries.pdf?sequence $=1$

Mariolis, T., Rodousakis, N. and Soklis, G. (2020), "The COVID-19 multiplier effects of tourism on the Greek economy", Tourism Economics, Vol. 27, No. 8., pp. 1848-1855. https://doi.org/10.1177/1354816620946547

Marušić, Čorak, Ivandić, Beroš and Andrušec, (2020), "Stavovi i potrošnja turista u Hrvatskoj - TOMAS Hrvatska 2019”, Institut za turizam, Zagreb, viewed 10 March 2021, http://www.iztzg.hr/hr/institut/projekti/istrazivanja/

McLennan, W. (2006), Information paper: Australian national accounts: Introduction to input-output multipliers, No. 5246.0, Australian Bureau of Statistics.

Mikulić, D., Keček, D. and Žajdela Hrustek, N. (2017), "Overall contribution of the foreign tourist demand on Croatian economy", in 4th International Scientific Conference ToSEE-Tourism in Southern and Eastern Europe 2017" Tourism and Creative Industries: Trends and Challenges" Opatija, Croatia, 4-6 May 2017, Faculty of Tourism and Hospitality Management, University of Rijeka, pp. 393407.

Miller, R.E. and Blair P.D. (2009), Input-Output Analysis: Foundations and Extensions, Cambridge University Press, New York.

Ribeiro, L.C.S., Santos, G.F., Cerqueira, R.B., and Souza, K.B. (2020), "Economic impact of Covid-19 on tourism in Brazil", 10.13140/RG.2.2.10902.78405, viewed 10 March 2021, https://www.researchgate.net/publication/341805042_Economic_impact_of_Covid19_on_tourism_in_Brazil/citations

Saayman, M., Saayman, A. and Naudé, W. (2011), "Economic And Sectoral Effects Of Tourist Spending In South Africa: Regional implications", ABAS International Conference, 10-12 July, Prague, Czech Republic.

Surugiu, C., Frent, C. and Surugiu, M. (2009), "Tourism and its impact upon the Romanian economy: an inputoutput approach", Analele Stiintifice ale Universitatii "Alexandru Ioan Cuza" din Iasi - Stiinte Economice, Vol. 56, pp. 355-376.

Šutalo, I., Ivandić, N. and Marušić, Z. (2011), "Ukupan doprinos turizma gospodarstvu Hrvatske: Input-Output model i satelitski račun turizma”, Ekonomski pregled, Vol. 62, No. 5-6, pp. 267-285.

Gössling, S, Scott, D. and Hall, C.M. (2020), "Pandemics, tourism and global change: a rapid assessment of COVID-19," J. Sustain. Tour., pp. 1-20.

Tohmo, T. (2018), "The economic impact of tourism in Central Finland: a regional input-output study", Tourism review, Vol. 73, No. 4, pp. 521-547. doi: 10.1108/TR-04-2017-0080

UNWTO (2021), UNWTO World Tourism Barometer, https://www.e-unwto.org/toc/wtobarometereng/19/1 viewed: 10 March 2021, https://doi.org/10.18111/wtobarometereng 
ToSEE - Tourism in Southern and Eastern Europe, Vol. 6, pp. 439-453, 2021.

D. Mikulić, D. Keček, Ž. Lovrinčević: EXAMINING THE IMPACT OF COVID-19 PANDEMIC ON ...

Davor Mikulić, $\mathrm{PhD}$, Senior research fellow in permanent position Institute of Economics

Trg J. F. Kennedy 7, Zagreb, Croatia

$+385-1-2362235$

dmikulic@eizg.hr

Damira Keček, PhD, Assistant Professor

University North

104. brigade 3, Varaždin, Croatia

$+385-42-493370$

dkecek@unin.hr

Željko Lovrinčević, $\mathrm{PhD}$, Senior research fellow in permanent position Institute of Economics

Trg J. F. Kennedy 7, Zagreb, Croatia

$+385-1-2362200$

zlovrincevic@eizg.hr 